\title{
PKM Kelompok Ibu Rumah Tangga Sebagai Perawat Terbaik Dalam Perawatan Bayi Berat Badan Lahir Rendah (BBLR) di Rumah
}

\author{
PKM Housewife Mother Group as The Best Nurse in Care of Low Birth Weight (LBW) \\ Babies at Home
}

\author{
Diyan Indriyani ${ }^{*}$, Awatiful Azza ${ }^{2}$, Ria Angin ${ }^{2}$ \\ ${ }^{1}$ Fakultas Ilmu Kesehatan Universitas Muhammadiyah Jember \\ ${ }^{2}$ Fakultas Ilmu Sosial dan Politik Universitas Muhammadiyah Jember \\ *diyanindriyani@unmuhjember.ac.id
}

\begin{abstract}
ABSTRAK
Mitra merupakan kelompok ibu rumah tangga yang tinggal di wilayah Sumbersari Kabupaten Jember. Tujuan utama dari pelaksanaan program PKM yang berjudul "PKM Kelompok Ibu Rumah Tangga Sebagai Perawat Terbaik Dalam Perawatan Bayi Berat Badan Lahir Rendah (BBLR) di Rumah" ini adalah untuk mengatasi permasalahan Mitra berupa: (1) Masalah kurangnya pengetahuan dan pemahaman yang mendalam tentang bayi BBLR dan permasalahannya terhadap risiko sakit dan kematian bayi (2) Masalah kurangnya pengetahuan dan pemahaman tentang teknik perawatan bayi BBLR pasca hospitalisasi (3) Belum aktifnya peran ibu yang memiliki bayi BBLR terhadap sesamanya, dan (4) Belum optimalnya peran kader kesehatan dalam melakukan pendampingan dalam optimalisasi kemampuan ibu dalam perawatan bayi BBLR pasca hospitalisasi.. Target Target khusus dalam program PKM ini adalah. Solusi untuk permasalahan yang dihadapi Mitra tersebut, perlu dilakukan tindakan berupa: 1) sosialisasi untuk motivasi ibu sebagai perawat terbaik bagi bayi yang dilahirkannya, 2) penyuluhan tentang mengenal bayi BBLR dan permasalahannya, 3) penyuluhan tentang mengenal kondisi sehat-sakit pada bayi BBLR, 4) melakukan pelatihan tentang perawatan bayi BBLR dirumah secara komprehensif, 5) pelatihan Mitra menjadi edukator sebaya dan 6) pelatihan Mitra menjadi pendamping dalam edukator sebaya. Selanjutnya target kegiatan ini adalah menghasilkan produk berupa jasa pengetahuan dan pemahaman yang mendalam tentang teknik perawatan bayi BBLR di rumah. Jangka waktu pelaksanaan kegiatan PKM selama 8 bulan. Metode pendekatan yang ditawarkan untuk menyelesaikan persoalan mitra program PKM Kelompok ibu rumah tangga ini dengan tahapan yaitu: 1) melakukan koordinasi dengan ibu rumah tangga, 2) melakukan koordinasi dengan kader kesehatan., 3) melakukan sosialisasi untuk memotivasi ibu sebagai perawat terbaik bagi bayi BBLR di rumah, 4) melakukan sosialisasi tentang bayi BBLR dan permasalahannya, 5) melakukan Sosialisasi tentang kondisi sehat-sakit bayi BBLR, 6) melakukan pelatihan tentang perawatan bayi BBLR dirumah secara komprehensif 7) melakukan Sosialisasi menjadi edukator sebaya dan 8) melakukan Sosialisasi kader kesehatan menjadi pendamping edukator sebaya.
\end{abstract}

Kata kunci - Ibu Rumah Tangga, BBLR, Perawat Terbaik, di Rumah

\begin{abstract}
Mitra is a group of housewives who live in the Sumbersari area, Jember Regency. The main purpose of the implementation of the PKM program entitled "Housewife Group PKM as the Best Nurse in Caring for Low Birth Weight Babies (LBW) at Home" is to overcome Partner problems in the form of: (1) The problem of lack of knowledge and in-depth understanding of infants LBW and its problems with the risk of illness and infant mortality (2) The problem of lack of knowledge and understanding of LBW infant care techniques after hospitalization (3) The inactive role of mothers who have LBW babies towards each other, and (4) The role of health cadres in providing assistance is not yet optimal in optimizing the mother's ability to care for $L B W$ babies after hospitalization. The specific targets in this PKM program are. Solutions to the problems faced by these partners, it is necessary to take actions in the form of: 1) socialization for mother's motivation as the best nurse for babies born to them, 2) counseling about getting to know LBW babies and their problems, 3) counseling about getting to know healthy-ill conditions in LBW babies, 4) conduct training on comprehensive care of $L B W$ babies at home, 5) training partners to become peer educators and 6) training partners to become companions in peer educators. Furthermore, the target of this activity is to produce products in the form of services for in-depth knowledge and understanding of LBW baby care techniques at home. The period of implementation of PKM activities is 8 months. The approach method offered to solve the problems of PKM program partners This housewife group is carried out in stages, namely: 1) coordinating with housewives, 2) coordinating with health cadres, 3) conducting socialization to motivate mothers as the best nurses for LBW babies. at home, 4) conduct socialization about LBW babies and their problems, 5) conduct socialization about the health and illness conditions of $L B W$ babies, 6) conduct training on comprehensive care for $L B W$ babies at home 7) conduct socialization to become peer educators and 8) conduct socialization for health cadres be a peer educator.
\end{abstract}

Keywords - Housewife, LBW, Best Nurse, at Home 


\section{Pendahuluan}

Bayi Berat Badan Lahir Rendah (BBLR) adalah bayi yang lahir dengan berat badan kurang dari 2500 gram, yang ditimbang pada saat lahir sampai dengan 24 jam pertama setelah lahir. Bayi Berat Badan Lahir Rendah (BBLR) yaitu bayi baru lahir yang berat badannya 2500 gram atau lebih rendah tanpa memandang masa gestasi (Saputra, 2014 [9]).

Bayi baru lahir BBLR berisiko karena sistem organ yang immatur dan kurangnya cadangan lemak tubuh. Bayi memerlukan adaptasi terhadap kehidupan ekstrauterin agar dapat bertahan hidup. Kondisi adaptasi awal dari bayi BBLR yang perlu mendapat perhatian adalah penyesuaian suhu tubuh terhadap lingkungan, juga tipisnya bantalan lemak tubuh. Bayi baru lahir BBLR mengalami kesulitan untuk mengatur suhu tubuhnya karena penurunan insulasi lemak dan perbandingan antara area permukaan yang luas terhadap berat badan.

Problem klinis lebih sering terjadi dibandingkan dengan bayi yang normal. BBLR menimbulkan imaturitas perkembangan dan fungsi sistem, membatasi kemampuan bayi untuk melakukan koping terhadap masalah penyakit. Masalah yang umum terjadi diantaranya respiratory disstres syndrom (RDS), masalah sistem imunologi, masalah gastrointestinal, masalah hati, masalah sistem syaraf pusat dan masalah suhu. Stressor tambahan lain yakni pada respon orang tua dan mekanisme koping terhadap bayi dapat menimbulkan gangguan pada hubungan antara mereka. Diperlukan perencanaan dan tindakan yang adekuat dan tepat untuk permasalahan tersebut (Gomella et all, 2013 [5]).

Guna mengatasi masalah kesehatan pada bayi BBLR dibutuhkan perawatan yang komprehensif yakni sebaiknya di rawat di rumah sakit. Hal ini karena bayi BBLR masih membutuhkan cairan-cairan, pengobatan, perawatan serta pemeriksaan laboratorium yang bertujuan untuk menyelamatkan keberlangsungan hidup bayi. Salah satu alternatif perawatan bayi BBLR dapat dilakukan dengan metode kanguru/ Kangaroo Mother Care (KMC). Cara ini sangat efektif dan efisien karena dapat dilakukan oleh ibu dan anggota keluarga (MCHIP, 2012 [10]).
Secara Statistik data menunjukkan 90\% kejadian BBLR didapatkan di negara berkembang dan dengan angka kematian lebih tinggi dibandingkan pada bayi dengan berat lahir lebih dari 2500 gram (Pantiawati, 2010). Sebanyak 15 juta bayi terlahir BBLR setiap tahun. Data pada tahun 2013 menunjukkan angka kelahiran bayi pada tahun 2010 sebanyak 4.371.800 jiwa. Dari jumlah tersebut, satu dari enam yang lahir mengalami BBLR atau 15,5 per 100 kelahiran hidup (675.700 jiwa) terlahir BBLR (IDAI, 2014 [3]). Dinas Kesehatan Provinsi Jawa Timur pada Tahun 2012 menyatakan bahwa jumlah bayi dengan BBLR di Jawa Timur mencapai 3,32\% yang diperoleh dari persentase 19.712 dari 594.461 bayi baru lahir yang di timbang.

Kabupaten Jember masih banyak bayi BBLR dengan IUGR karena ibu berstatus gizi buruk, anemia, dan menderita penyakit menular seksual (PMS) sebelum konsepsi atau pada saat hamil. Berdasarkan laporan Seksi Kesehatan Keluarga dan Gizi Masyarakat Dinas Kesehatan Kabupaten Jember, jumlah bayi lahir dengan Berat Badan Lahir Rendah (BBLR) tahun 2016 sebanyak 1.564 dari 36.260 bayi baru lahir ditimbang $(4,3 \%)$. Jumlah bayi BBLR pada tahun ini menurun bila dibandingkan dari tahun sebelumnya (Dinkes Jember, 2017 [1]).

Saat bayi BBLR dalam perawatan di rumah sakit, maka kondisi bayi akan terkontrol dan mendapatkan pengawasan intensif dan ketat. Berbagai upaya medis dilakukan untuk meningkatkan status kesehatan bayi BBLR agar dapat bertahan dalam kehidupan ekstra uterine secara optimal. Namun kondisi permasalahan bisa muncul saat bayi sudah dinyatakan boleh pulang dan memerlukan perawatan lanjutan di rumah. Tingkat kesiapan orang tua dalam melakukan perawatan bayi BBLR setelah pulang dari perawatan di RS sangat bervariasi. Hal yang juga sering terjadi adalah keluarga (ibu rumah tangga) belum kompeten dalam melakukan perawatan hingga berdampak timbulnya kondisi sakit pada bayi bahkan mengancam keselamatan bayi.

Kasus angka kesakitan yang terjadi pada bayi BBLR pasca hospitalisasi ini sangat memerlukan kewaspadaan dan bantuan untuk diselesaikan. Karena pada saat bayi BBLR 
mengalami kondisi sakit dampak perawatan yang kurang tepat, hal ini memiliki risiko prognosis yang lebih buruk dibandingkan bayi yang lahir dengan kondisi normal (Dinkes Jember, 2014[1]). Peningkatan kompetensi ibu yang memiliki bayi BBLR tentang perawatan bayi BBLR sangat diperlukan untuk mempertahankan status kesehatan bayi. Namun faktanya didapatkan kondisi bahwa masih rendahnya pengetahuan dan pemahaman tentang teknik perawatan bayi BBLR pasca hospitalisasi (Indriyani, Asih dan Wahyuni, 2018). Kondisi ini juga terjadi di kelompok ibu rumah tangga dengan bayi BBLR pasca hospitalisasi di Desa Sumbersari Kecamatan Sumbersari Kecamatan Sumbersari Kabupaten Jember .

Masalah yang dihadapi kelompok ibu rumah tangga yang memiliki bayi BBLR tersebut jika dibiarkan akan mengakibatkan kondisi pemburukan status kesehatan bayi BBLR sampai mengancam keselamatan bayi dampak kurangnya pengetahuan ibu rumah tangga tentang tehnik perawatan bayi BBLR di rumah secara tepat. Berdasarkan paparan di atas dan hasil diskusi dengan Mitra maka dapat diungkapkan bahwa Mitra memiliki masalah tentang belum optimalnya keterampilan ibu rumah tangga dalam perawatan bayi Berat Badan Lahir Rendah (BBLR). Hal ini perlu dilakukan intervensi sebagai solusi untuk membantu mengatasi permasalahan Mitra yang fokusnya dalam mengoptimalkan kemampuan ibu rumah tangga dalam perawatan bayi BBLR di rumah, untuk mencegah keadaan sakit dan bahkan risiko meninggal sebagai upaya menurunkan angka kematian bayi.

\section{Target dan Luaran}

Sasaran Target luaran yang diharapkan dalam kegiatan PKM ini adalah Persepsi dan keterampilan ibu rumah tangga pada Mitra tentang perawatan bayi BBLR di rumah meningkat dan tepat serta mampu menjadi edukator sebaya bagi anggota kelompoknya.

\section{Metodologi}

\subsection{Tahap Persiapan}

Pengurusan administrasi/perijinan ke Bakesbang dan Linmas Kabupaten Jember, kemudian diteruskan ke Dinas Kesehatan Kabupaten Jember. Setelah itu ditindaklanjuti ke Puskesmas Sumbersari untuk mempersiapkan segala sesuatu yang diperlukan (jadwal kegiatan, tempat kegiatan, media yang akan digunakan, dan bagaimana kegiatan nanti akan dilakukan)

\subsection{Tahap Pelaksanaan}

a. Melakukan Koordinasi dalam mengumpulkan ibu rumah tangga

b. Melakukan Koordinasi dengan ketua paguyuban kader dan kader kesehatan Wilayah Sumbersari.

c. Melakukan Sosialisasi pengetahuan dan pemahaman yang mendalam pada kelompok ibu rumah tangga tentang mengenal bayi BBLR,

d. Melakukan Sosialisasi pengetahuan, pemahaman dan keterampilan pada kelompok ibu rumah tangga tentang tehnik Kangaroo Mother Care (KMC).

e. Melakukan Sosialisasi pengetahuan, pemahaman dan keterampilan pada kelompok ibu rumah tangga tentang perawatan sehari-hari bayi BBLR di rumah.

f. Melakukan Sosialisasi pengetahuan, pemahaman dan keterampilan pada kelompok ibu rumah tangga tentang stimulasi pertumbuhan dan perkembangan bayi BBLR.

g. Melakukan Sosialisasi pengetahuan, pemahaman dan keterampilan pada kelompok ibu rumah tangga tentang pemijatan pada bayi BBLR.

h. Melakukan Sosialisasi pengetahuan dan pemahaman mendalam pada kelompok ibu rumah tangga tentang tehnik menjadi edukator sebaya.

i. Melakukan Sosialisasi pengetahuan, pemahaman dan keterampilan pada kader kesehatan tentang perawatan bayi BBLR di rumah. Melakukan Sosialisasi pengetahuan, pemahaman dan keterampilan pada kader kesehatan tentang tehnik menjadi pendamping edukator sebaya.

\subsection{Tahap Evaluasi}

\subsubsection{Evaluasi proses kegiatan}

Kegiatan yang dilakukan pada tahap ini adalah melakukan evaluasi terhadap proses 
kegiatan PKM mulai dari awal sampai dengan akhir.

\subsubsection{Evaluasi hasil kegiatan}

Evaluasi hasil dapat mengetahui tingkat capaian tujuan PKM antara lain: pemahaman tentang mengenal bayi BBLR, pemahaman dan keterampilan tentang tehnik Kangaroo Mother Care (KMC), pemahaman dan keterampilan tentang perawatan sehari-hari bayi BBLR di rumah, pemahaman dan keterampilan tehnik stimulasi pertumbuhan dan perkembangan bayi BBLR, pemahaman dan keterampilan tentang tehnik pijat bayi BBLR, pemahaman tentang strategi menjadi edukator sebaya, pemahaman dan keterampilan kader kesehatan tentang perawatan bayi BBLR di rumah dan pemahaman tentang tehnik menjadi pendamping edukator sebaya.

\subsubsection{Evaluasi dampak kegiatan}

Evaluasi dampak kegiatan adalah dengan melihat efek kegiatan yang dilihat dari kemampuan ibu rumah tangga dalam melakukan perawatan sehari-hari bayi BBLR di rumah, maka bayi menjadi sehat, dan dapat mengurangi kemungkinan sakit termasuk risiko kematian pada bayi BBLR.

\section{Pembahasan}

Kegiatan PKM ini difokuskan pada kelompok ibu rumah tangga yang ada di di wilayah Sumbersari Kabupaten Jember yang menghadapi masalah belum optimalnya kemampuan perawatan bayi BBLR di rumah pasca hospitalisasi. Adapun kegiatannya dilaksanakan sebagai berikut:

\subsection{Persiapan Dan Perijinan Pelaksanaan PKM}

Tim pelaksana melakukan persiapan pelaksanaan PKM secara teknis dan operasional agar mudah dalam proses pelaksanaannya. Hal ini dilakukan dengan cara koordinasi dengan Ketua LPPM Universitas Muhammadiyah Jember. Selain hal tersebut Tim Pelaksana juga melengkapi segala hal yang berkaitan dengan kelengkapan literatur guna menunjang dalam proses implementasi program. Kegiatan koordinasi ini dilakukan sampai tujuan dan rencana kegiatan PKM dimungkinkan siap untuk mulai dilakukan.

Tim pelaksana meminta ijin untuk pelaksanaan PKM Kelompok Ibu Rumah Tangga Sebagai Perawat Terbaik Dalam Perawatan Bayi Berat Badan Lahir Rendah (BBLR) di Rumah ini dengan mengajukan permohonan ijin dari Fakultas Ilmu Kesehatan (tanggal 13 April 2019) ke Bakesbangpol Kabupaten Jember. Berdasarkan surat ijin dari Bakesbangpol yang telah didapatkan yaitu tanggal 23 April 2019 tim Pelaksana melanjutkan rekomendasi ijin ke Kepala Dinas Kesehatan Kabupaten Jember. Hasil ijin dari Ka. Dinkes Kabupaten Jember tanggal 24 April 2019 tersebut berupa kelanjutan surat ke Puskesmas Sumbersari Kabupaten Jember.

\subsection{Koordinasi dengan Ibu Rumah Tangga, di Wilayah Sumbersari Jember}

Melakukan Koordinasi dengan Ketua Paguyuban Posyandu dalam mengumpulkan ibu Rumah Tangga Tim pelaksana telah mengundang Mitra dalam rangka melakukan koordinasi untuk pelaksanaan program PKM yang dilaksanakan tanggal 10 Mei 2018. Hadir dalam kegiatan tersebut Ketua Paguyuban Kader Posyandu Wilayah Sumbersari Kabupaten Jember. Pada koordinasi tersebut disepakati bahwa perlu berkoordinasi kembali dengan kader penanggungjawab masing-masing wilayah di Sumbersari, yang disepakati untuk dilaksanakan tanggal 16 Mei 2019. Melalui pertemuan dengan ketua Paguyuban kader Posyandu wilayah Sumbersari tersebut, juga didapatkan gambaran area pemetakan wilayah untuk pelaksanaan Posyandu dimana terdapat lokasi ibu Rumah Tangga yang memiliki bayi dengan kasus BBLR.

\subsection{Koordinasi dengan Ketua Paguyuban Kader dan Kader Kesehatan Penanggungjawab Masing-masing Wilayah Posyandu di Sumbersari Jember}

Ketua pelaksana bersama team melakukan koordinasi lanjutan tanggal 16 Mei 2019 dengan Ketua Paguyuban Kader Posyandu dan Kader Kesehatan penanggungjawab masing-masing wilayah Posyandu sebanyak 7 orang untuk melaksanakan kegiatan PKM yang 
direncanakan. Melalui koordinasi tersebut diputuskan bahwa 7 personil tersebut untuk mendampingi pelaksanaan kegiatan PKM dari awal sampa akhir. Ketua Paguyuban Kader Posyandu yaitu Lilik Musriah, penanggungjawab kader kesehatan masing-masing wilayah pada Posyandu di Sumbersari yaitu: Setya Candra, Cicik Ari W, Ida S, Yayuk Supiyati, Irfatul A'la, Sri Pstutik, dan jumlah ibu RT yang menjadi subyek dalam kegiatan PKM sebanyak 12 orang. Hasil koordinasi disepakati dalam pelaksanaan kegiatan PKM disepakati yaitu: 1) pertemuan pertama melaksanakan FGD pada hari Sabtu tanggal 25 Mei 2019. 2) Pertemuan kedua pelatihan 1 tentang mengenal bayi BBLR, tehnik Kangooro mother care (KMC), perawatan bayi BBLR di rumah pada hari Sabtu tanggal 22 Juni 2019 , 3) Untuk pertemuan ketiga pelatihan 2 yaitu hari Sabtu tanggal 29 Juni 2019 tentang stimulasi tumbang bayi BBLR, tehnik massage bayi BBLR, strategi menjadi edukator sebaya, 4) pertemuan keempat yaitu pelatihan kader pada hari Sabtu 20 Juli 2019 tentang perawatan bayi BBLR dan pendamping edukator sebaya, 5) penyerahan alat perawatan bayi pada koordinator kader tanggal 27 Juli 2019, 6) pertemuan berikutnya mengikuti jadwal Posyandu untuk aplikasi sebagai edukator sebaya.

\subsection{Pelaksanaan Focus Group Discussion (FGD)}

Kegiatan FGD dilaksanakan hari Sabtu 25 Mei 2019. Berkaitan dengan kelanjutan program bahwa tim pelaksana menyelenggarakan pelatihan pelatihan bagi calon edukator sebaya, maka sangat penting untuk dilakukan pengukuran persepsi dari ibu RT yang telah terpilih sebagai perwakilan ibu RT di masingmasing wilayah hal-hal yang berkaitan dengan perawatan bayi BBLR di rumah. Oleh karena itu tim pelaksana melakukan Focus Group Discussion (FGD) yang memiliki tujuan utama untuk mengidentifikasi pengetahuan dasar yang sudah dimiliki oleh perwakilan ibu RT di kedua Wilayah Sumbersari.. Adapun hasil yang didapatkan dari proses FGD tersebut adalah sebagai berikut:

\subsubsection{Pemahaman tentang bayi BBLR}

Hasil diskusi kelompok dengan ibu RT yang memiliki bayi BBRL didapatkan gambaran persepsi adalah bayi dengan berat badan kurang dari 2500 gram, bayi berisiko kematian karena suhu badan tidak stabil, mudah terserang penyakit atau tertular penyakit, rentan terhadap bakteri, organ tubuhnya belum siap, bayi yang membutuhkan perawatan intensif, bayi sangat sensitif. Bayi BBLR disebabkan karena asupan gizi ibu kurang, dan ibu saat hamil sering sakit seperti asma, TBC, DM dan infeksi.

\subsubsection{Persiapan lingkungan untuk bayi BBLR}

Prinsip yang diketahui ibu RT terkait persiapan lingkungan untuk bayi BBLR adalah meliputi: menyediakan ruang untuk menghangatkan dengan diberi lampu, perawatan intensif pada bayi, diberi penghangat, suhu ruangan harus sesuai dan stabil, ruangan harus bersih, menghindari pemakaian AC, pagi hari bayi dijemur jam 7-7.30 namun pada malam hari dihangatkan menggunakan lampu, disiapkan air panas dalam botol dan dilapisi kain untuk menghangatkan

\subsubsection{Persepsi tentang tehnik Kangooro Mother Care (KMC)}

Perawatan bayi BBLR sehari-hari (pemberian nutrisi, memandikan bayi, perawatan tali pusat, buang air besar dan kecil) Melalui diskusi tersebut dikemukakan pendapat ibu RT bahwa: 1) KMC yaitu bayi digendong memakai tangan atau gendongan lalu didekap di dada posisi berdiri, bayi ditempelkan pada dada ibu tanpa ada kain sebagai pembatas sehingga kulit bayi dan ibu menempel untuk mendapatkan dekapan kasih sayang, cara melakukan posisi bayi pada ibu/keluarga supaya bayi mendapatkan kehangatan dan ikatan kasih dari ibu atau keluarganya, bayi yang didekap ke dada ibu, bayi yang didekap ke dada ibu tanpa kain, mendekapkan bayi ke dada ibu tanpa busana supaya hangat; 2) pemberian nutrisi bayi BBLR: bayi diberikan ASI bila usia kurang dari 6 bulan, memberi ASI eksklusif, setelah usia 6 bulan diberikan MPASI, bila bayi belum dapat menghisap dengan baik ibu RT belum tahu bagaimana cara memberi nutrisi pada bayi BBLR tersebut; 3) memandikan bayi BBLR: 
membersihkan menggunakan tisu basah atau kapas basah yang sudah disteril, memakai kain basah atau tisu basah tapi hanya sebagian saja, cukup di lap pada bagian badan bayi, dengan diseka, dimandikan dengan suhu air yang sesuai dengan suhu tubuh, tidak boleh dimandikan tapi diseka sampai berat badan sesuai, menggunakan minyak telon; 4) perawatan tali pusat bayi BBLR: tali pusat dirawat menggunakan kasa kering, ditutup pakai kain kasa, menggunakan kapas basah yang sudah disterilkan terlebih dahulu, perawatan tali pusat sama saja dengan perawatan tali pusat pada bayi dengan BB normal; 5) perawatan $\mathrm{BAB}$ dan BAK: popok dibuka, dibersihkan menggunakan tisu basah dan popok diganti, menggunakan kain basah, merawat memakai kapas direbus lalu ditempatkan pada toples yang steril, setelah BAB dan BAK tetap dibersihkan menggunakan kapas dan air saja, tanpa memberi bedak

\subsubsection{Stimulasi pertumbuhan dan perkembangan bayi BBLR}

Stimulasi tumbuh kembang pada bayi BBLR sangat penting dan diperlukan. Melalui diskusi kelompok dengan ibu RT didapatkan gambaran bahwa cara melakukan stimulasi tumbang bayi BBLR yaitu meliputi: melalukan pemijatan, menghangatkan tubuh bayi pada pagi hari dan malam hari, memberikan ASI eksklusif, memberikan mainan yang berwarna dan berbunyi, mengajak bicara, memberi mainan, bila bayi menangis ibu segera menggendong, cara lain belum tahu.

\subsubsection{Cara melakukan pemijatan bayi BBLR}

Hasil diskusi dapat dikumpulkan data terkait pemijatan pada bayi BBLR: ibu RT menyatakan belum tahu dan belum pernah melakukan, selama ini yang diketahui pijat bayi dilakukan oleh dukun bayi.

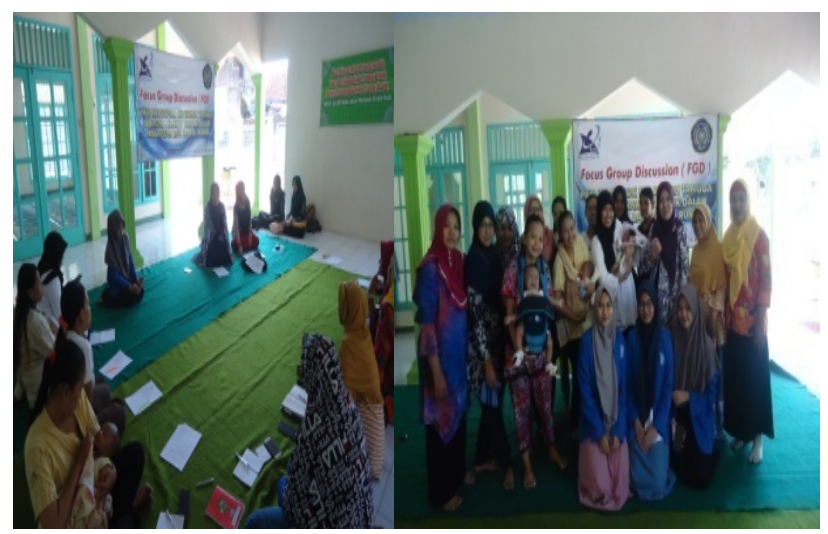

Gambar 1. Focus Group Discussion (FGD)

a. Pelatihan 1 tentang mengenal bayi BBLR, tehnik kangooro mother care dan perawatan bayi BBLR di rumah.

Tim pelaksana melakukan pelatihan 1 pada kelompok ibu rumah tangga yang memiliki bayi BBLR pada tanggal 22 Juni 2019. Pelatihan 1 ini dilaksanakan mulai jam 08.00-12.00 WIB. Adapun topik yang dibahas pada pelatihan 1 tersebut tentang mengenal bayi BBLR, tehnik kangooro mother care dan perawatan bayi BBLR di rumah. Sebelum dan sesudah dilakukan pelatihan kelompok ibu rumah tangga diukur persepsinya tentang topik tersebut. Tujuan pretest untuk mengidentifikasi sejauh mana persepsi yang sudah dimiliki kelompok ibu rumah tangga, dan tujuan posttest adalah guna melihat perubahan persepsi setelah dilakukan pelatihan. Kelompok ibu rumah tangga kooperatif selama mengikuti pelatihan. Adapun gambaran kesimpulan pemahaman kelompok ibu rumah tangga pada pelatihan 1 ini bahwa nilai mean pengetahuan sebelum pelatihan (pretest) pada topik mengenal bayi BBLR didapatkan nilai 65. Adapun nilai mean setelah pelatihan 1 (posttest) yaitu didapatkan nilai 76,67. Selain itu pada hasil ukur tersebut didapatkan nilai $\mathrm{p}(\mathrm{p}$ value) sebesar 0,01 yang artinya ada pengaruh pelatihan 1 terhadap pengetahuan ibu rumah tangga tentang mengenal bayi BBLR. Selain itu bahwa nilai mean pengetahuan sebelum pelatihan (pretest) pada topik tehnik Kangoroo Mother Care (KMC) didapatkan nilai 66,25. Adapun nilai mean setelah pelatihan 1 (posttest) yaitu didapatkan nilai 80,83 . Selain itu pada hasil ukur tersebut didapatkan nilai $\mathrm{p}$ ( $\mathrm{p}$ value) sebesar 0,00 yang artinya ada pengaruh pelatihan 1 terhadap pengetahuan ibu rumah tangga tentang 
tehnik kangoroo mother care (KMC). Melalui kegiatan pelatihan 1 kelompok ibu rumah tangga ini juga diketahui bahwa nilai mean pengetahuan sebelum pelatihan (pretest) pada topik perawatan sehari-hari bayi BBLR di rumah didapatkan nilai 60. Adapun nilai mean setelah pelatihan 1 (posttest) yaitu didapatkan nilai 80,42. Selain itu pada hasil ukur tersebut didapatkan nilai $\mathrm{p}(\mathrm{p}$ value) sebesar 0,01 yang artinya ada pengaruh pelatihan 1 terhadap pengetahuan ibu rumah tangga tentang perawatan sehari-hari bayi BBLR di rumah.

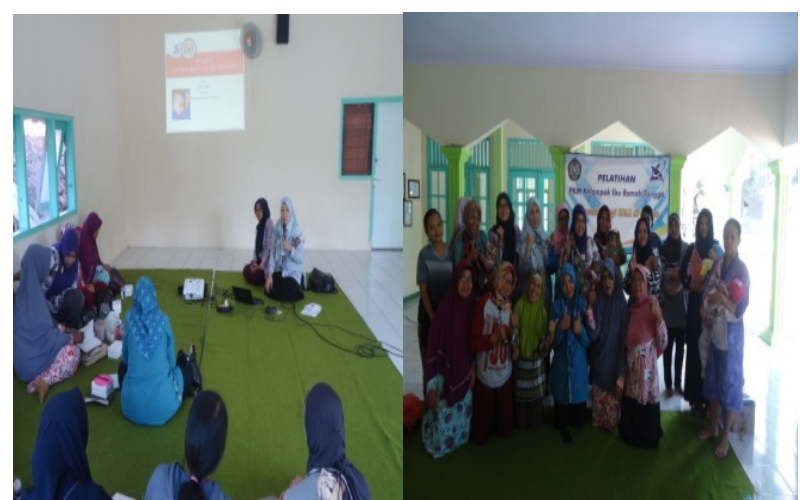

Gambar 2. Pelatihan 1 tentang mengenal bayi

BBLR, tehnik kangooro mother care dan perawatan bayi BBLR di rumah.

b. Pelatihan 2 tentang stimulasi tumbuh kembang, tehnik pijat bayi dan strategi menjadi edukator sebaya.

Pada pelatihan selanjutnya yaitu pelatihan 2 tim pelaksana melakukan pada hari Sabtu tanggal 29 Juni 2019. Pelatihan 2 ini juga dilaksanakan mulai jam 08.00-12.00 WIB. Topik yang dibahas pada pelatihan 2 tersebut tentang stimulasi tumbuh kembang, tehnik pijat bayi dan strategi menjadi edukator sebaya. Sebelum dan sesudah dilakukan pelatihan kelompok ibu rumah tangga diukur persepsinya tentang topik tersebut. Kelompok ibu rumah tangga dapat mengikuti pelatihan dengan seksama. Hal ini dibuktikan dengan banyaknya pertanyaan yang disampaikan saat memasuki sesi tanya jawab. Adapun gambaran kesimpulan pemahaman kelompok ibu rumah tangga pada pelatihan 2 ini yakni nilai mean pengetahuan sebelum pelatihan (pretest) pada topik stimulasi tumbuh kembang bayi BBLR didapatkan nilai 62,08. Adapun nilai mean setelah pelatihan 2 (posttest) yaitu didapatkan nilai 70,50. Selain itu pada hasil ukur tersebut didapatkan nilai $\mathrm{p}$ ( $\mathrm{p}$ value) sebesar 0,032 yang artinya ada pengaruh pelatihan 2 terhadap pengetahuan ibu rumah tangga tentang stimulasi tumbuh kembang bayi BBLR. Juga melalui kegiatan pelatihan 2 ini bahwa nilai mean pengetahuan sebelum pelatihan (pretest) pada topik tehnik pijat bayi BBLR didapatkan nilai 62,08 . Adapun nilai mean setelah pelatihan 2 (posttest) yaitu didapatkan nilai 79,33. Selain itu pada hasil ukur tersebut didapatkan nilai $\mathrm{p}(\mathrm{p}$ value) sebesar 0,00 yang artinya ada pengaruh pelatihan 2 terhadap pengetahuan ibu rumah tangga tentang. Tehnik pijat bayi BBLR. Topik strategi menjadi edukator sebaya juga diberikan saat pelatihan 2. Hasilnya yaitu nilai mean pengetahuan sebelum pelatihan (pretest) pada topik strategi menjadi edukator sebaya didapatkan nilai 59,17. Adapun nilai mean setelah pelatihan 2 (posttest) yaitu didapatkan nilai 76,25. Selain itu pada hasil ukur tersebut didapatkan nilai $\mathrm{p}$ ( $\mathrm{p}$ value) sebesar 0,00 yang artinya ada pengaruh pelatihan 2 terhadap pengetahuan ibu rumah tangga tentang strategi menjadi edukator sebaya.

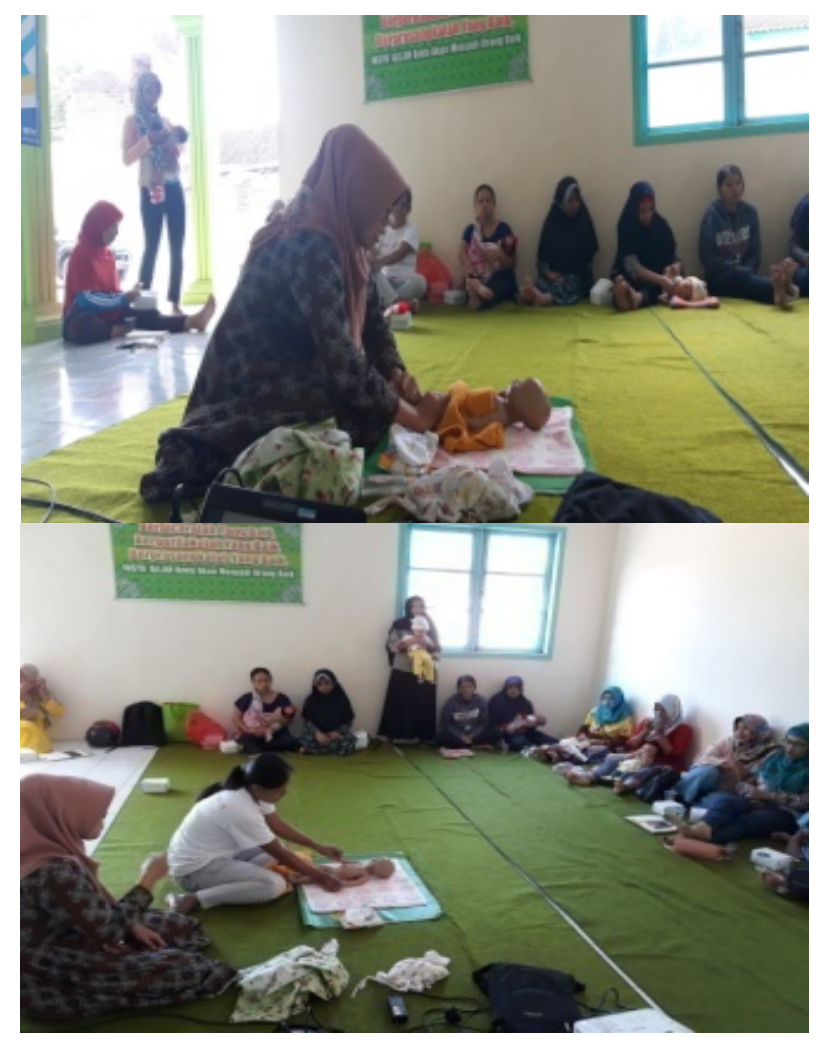

Gambar 3. Pelatihan 2 tentang stimulasi tumbuh kembang, tehnik pijat bayi dan strategi menjadi edukator sebaya. 


\section{c. Pelatihan 3 tentang Pelatihan Kader Kesehatan}

Pelatihan 3 yang dilakukan oleh tim pelaksana merupakan pelatihan pada kader Posyandu di Wilayah Sumbersari sebanyak 40 kader Posyandu. Pelatihan ini dilaksanakan pada tanggal 20 Juli 2019 mulai pukul 08.00-12.00. Hadir juga pada kegiatan pelatihan tersebut Kepala Puskesmas Sumbersari dan penanggungjawab kader Posyandu pada Wilayah Puskesmas Sumbersari. Kegiatan pelatihan kader ini untuk menguatkan pemahaman kader Posyandu tentang: 1) perawatan bayi BBLR; 2) Tehnik pendampingan pada edukator sebaya. Peserta kader Posyandu sangat kooperatif dalam mengikuti kegiatan pelatihan dari awal hingga akhir kegiatan. Sebelum dan sesudah melakukan pelatihan, tim pelaksana melakukan pengukuran pemahaman dalam bentuk pretest dan posttest. Pada kegiatan pelatihan 3 pada kader Posyandu di Wilayah bahwa nilai mean pengetahuan sebelum pelatihan (pretest) pada topik perawatan bayi BBLR di rumah didapatkan nilai 72,07. Adapun nilai mean setelah pelatihan 2 (posttest) yaitu didapatkan nilai 83,40 . Selain itu pada hasil ukur tersebut didapatkan nilai $\mathrm{p}$ ( $\mathrm{p}$ value) sebesar 0,01 yang artinya ada pengaruh pelatihan 3 terhadap pengetahuan Kader Posyandu Wilayah Sumbersari tentang perawatan bayi BBLR di rumah. Berkaitan dengan kegiatan pelatihan 3 juga didapatkan nilai mean pengetahuan sebelum pelatihan (pretest) pada topik tehnik pendampingan edukator sebaya didapatkan nilai 63,20 . Adapun nilai mean setelah pelatihan 3 (posttest) yaitu didapatkan nilai 78,50. Selain itu pada hasil ukur tersebut didapatkan nilai $\mathrm{p}$ ( $\mathrm{p}$ value) sebesar 0,02 yang artinya ada pengaruh pelatihan 3 terhadap pengetahuan Kader Posyandu Wilayah Sumbersari tentang tehnik pendampingan edukator sebaya.

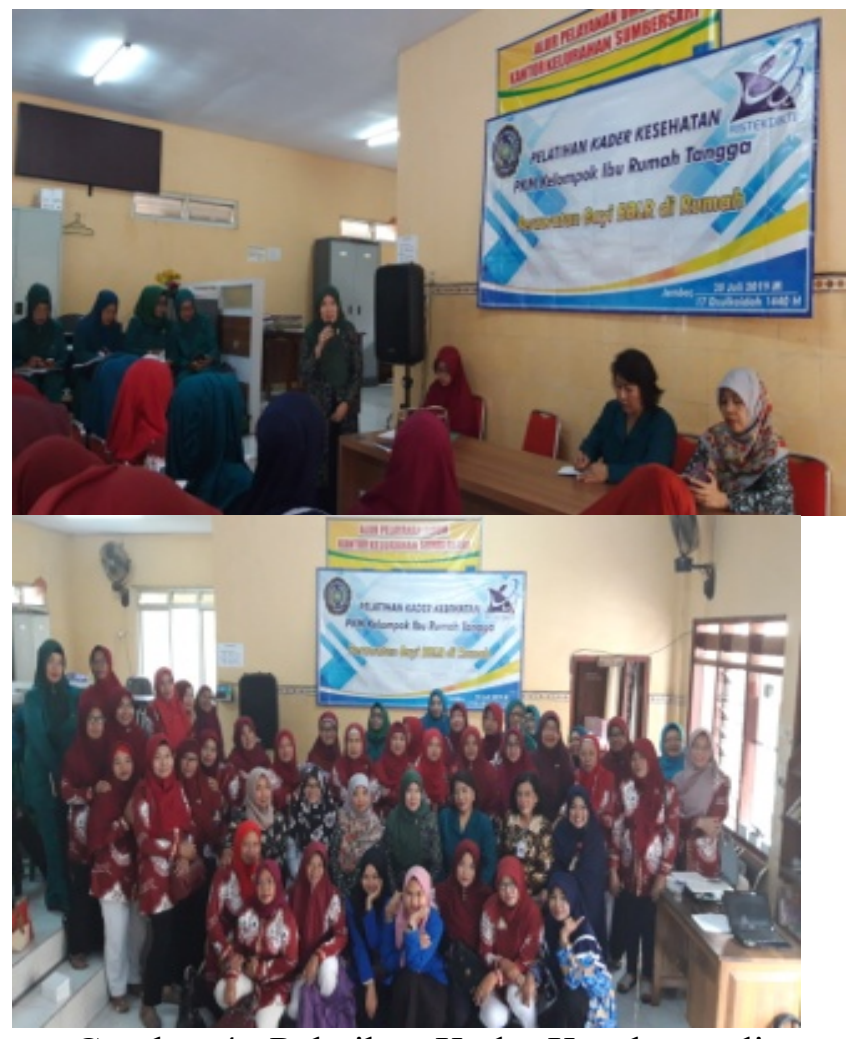

Gambar 4. Pelatihan Kader Kesehatan di Wilayah Sumbersari Jember

Dengan berakhirnya kegiatan pelatihan selanjutnya tim pelaksana melakukan pendampingan pada kelompok ibu rumah tangga dalam melakukan edukator pada kelompok sebayanya terutama saat pelaksanaan Posyandu. Guna memudahkan proses edukasi, maka tim pelaksana memberikan bantuan seperangkat media untuk memudahkan dalam pemberian edukasi, yang dilakukan pada tanggal 27 Juli 2019 .

d. PKM yang ditransfer pada Mitra I dan Mitra II (Bagan 1)

Berkaitan dengan kegiatan program PKM yang ditransfer pada Mitra yaitu dalam meningkatkan kemampuan ibu rumah tangga dalam perawatan bayi BBLR di rumah tergambar pada bagan 1 di bawah ini: 


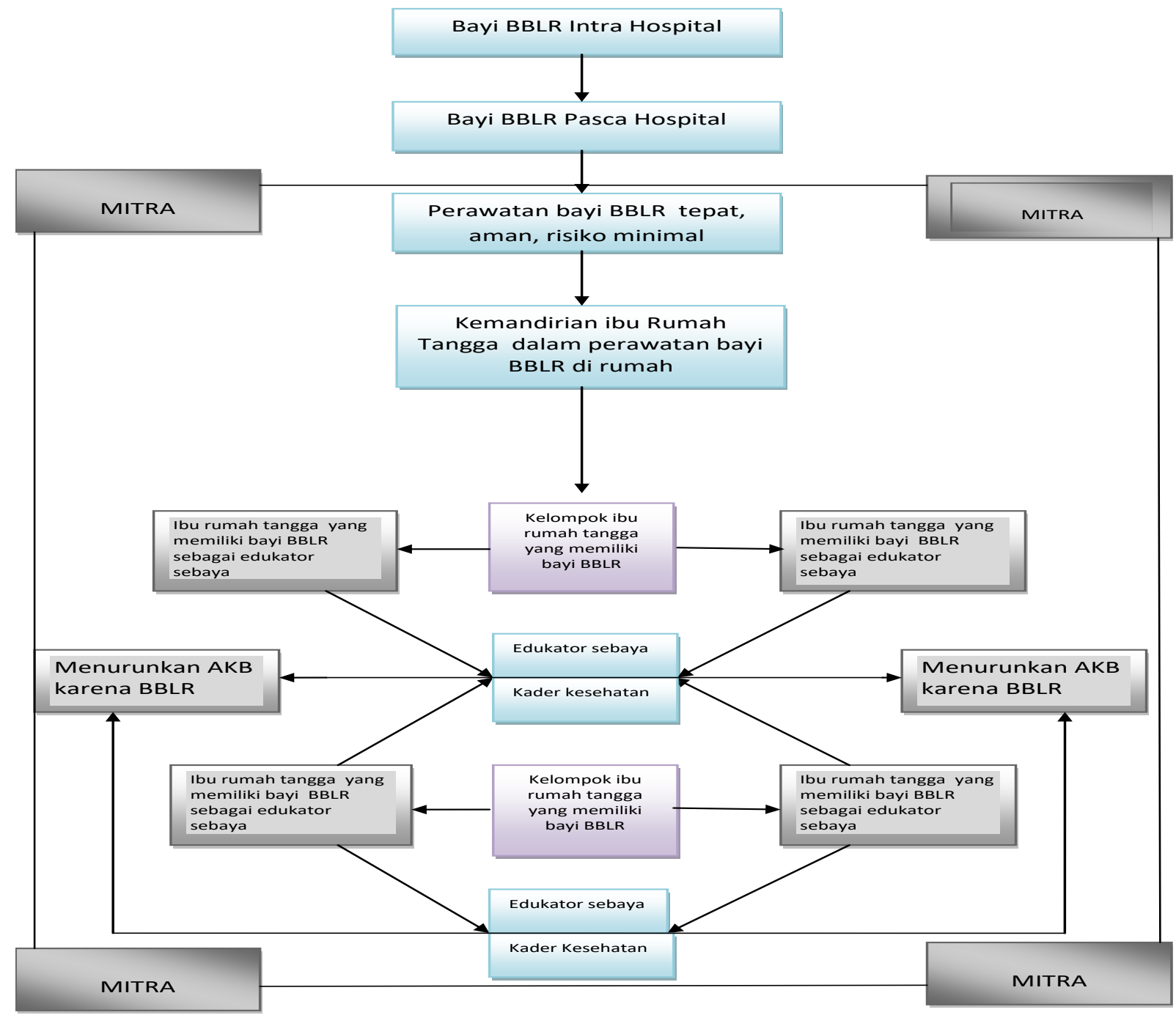

Gambar 5. Program PKM Yang Ditransfer Kepada Mitra di Wilayah Puskesmas Sumbersari Kabupaten Jember

Pada perawatan bayi, seorang ibu memiliki suatu naluri yang muncul begitu saja (spontan) dalam bentuk kepedulian seorang ibu terhadap bayinya, yang disebut mother instinct. Kondisi bayi yang dilahirkan dengan berat badan kurang dari normal (kurang 2.500 gram), membutuhkan proses perawatan aman yang dimulai dari perawatan intensif di rumah sakit. Bayi akan menjalani proses hospitalisasi. Pendekatan yang digunakan dalam perawatan bayi ini adalah Family Centered Care (FCC) yang merupakan perawatan dengan melibatkan keluarga secara aktif dalam perawatan bayi. Kondisi ini diperlukan situasi kerja sama yang kondusif antara petugas kesehatan dan keluarga, terutama ibu yang memiliki intensitas interaksi yang lebih banyak dengan bayi karena proses pemberian nutrisi atau menyusui. Pasca perawatan rumah sakit, bayi yang sudah memiliki kondisi stabil dalam ukuran berat badan meningkat, refleks hisap baik dan tidak ada tanda-tanda infeksi, maka bayi akan dipulangkan dan berada pada asuhan perawatan oleh keluarga. Pada situasi perawatan di rumah, ibu harus diberikan motivasi yang kuat untuk meyakini, bahwa ibu adalah perawat terbaik bagi bayi saat berada dalam perawatan di rumah, sehingga pemahaman ibu tentang perawatan bayi BBLR harus ditingkatkan dan dioptimalkan. 
Pengalaman menjadi ibu pada bayi
berisiko yaitu keterampilan dalam mempertahankan kelangsungan hidup bagi bayi. Hal ini karena bayi BBLR memiliki risiko yang berkaitan dengan immaturitas tubuh, rentan terhadap infeksi termasuk salah satunya adalah ketidakmampuan secara spontan dalam beradaptasi terhadap perubahan suhu lingkungan. Kondisi ini disebabkan karena selain immaturitas pusat pengatur suhu (hipotalamus), juga bantalan lemak tubuh sangat tipis (Indriyani, Asih dan Wahyuni, 2018 [4]). Salah satu hal yang sangat memungkinkan dalam membantu kondisi adaptasi suhu tubuh bayi BBLR adalah dengan memberikan lingkungan yang hangat, termasuk tehnik perawatan Kangaroo Mother Care (KMC).

Kelebihan pelaksanaan KMC di rumah yaitu bisa dilakukan bukan hanya oleh ibu, tapi juga bisa oleh anggota keluarga yang lain seperti ayah bayi. Berkaitan dengan pentingnya kemampuan ibu dalam melakukan tehnik KMC di rumah dalam membantu adaptasi suhu tubuh bayi BBLR ini yaitu penelitian yang dilakukan oleh Lestari, Arif dan Alit (2019) yang mendapatkan hasil penelitian bahwa terdapat hubungan antara pengetahuan ibu dengan implementasi $\mathrm{KMC}$, terdapat hubungan yang signifikan sikap ibu dengan implementasi KMC dan hubungan signifikan dukungan keluarga dengan implementasi KMC. Keberhasilan untuk mempertahankan kesehatan pada bayi BBLR bukan hanya tergantung saat perawatan bayi di rumah sakit, melainkan kelanjutan saat perawatan bayi BBLR di rumah juga sangat penting untuk mendapat perhatian dan perawatan secara tepat. Untuk menerapkan KMC di rumah membutuhkan sikap yang optimal dari ibu termasuk anggota keluarganya. Hal ini selaras dengan penelitian Kusumawardani dan Cholifah (2019) [6] bahwa ada hubungan sikap ibu dengan pelaksanaan metode kangguru pada bayi berat lahir rendah sehingga diharapkan masyarakat dan petugas kesehatan untuk melaksanakan metode kangguru pada bayi berat lahir rendah baik di layanan kesehatan maupun di rumah. Menurut peneliti bahwa keberhasilan perawatan bayi BBLR di rumah dalam mempertahankan suhu tubuh yang normal sangat memerlukan kolaborasi dari ibu dan keluarga serta pemberian informasi oleh petugas kesehatan.

Melalui tahapan-tahapan pendekatan model PKM yang ditransfer ke Mitra tersebut tim pelaksana mendapatkan dukungan dari Mitra. Mitra sangat antusias dalam mengikuti kegiatan, kelompok ibu rumah tangga yang didampingi kader kesehatan sangat disiplin dan antusias mengikuti jadwal yang telah ditetapkan bersama, Puskesmas juga memfasilitasi dan mensupport kegiatan ini. Hal ini karena aktivitas ini memiliki sinergisme dengan program kesehatan ibu dan anak (KIA) yang memiliki tujuan akhir (outcome) untuk mendukung penurunan $\mathrm{AKI}$ dan $\mathrm{AKB}$

\section{Kesimpulan}

a. Tahapan koordinasi dan sosialisasi Program Kemitraan Masyarakat (PKM) pada kelompok ibu rumah tangga dapat dilaksanakan dengan baik sesuai rencana. Mitra sangat responsif untuk mendukung kegiatan pengabdian masyarakat ini.

b. Tahapan untuk pembentukan kelompok ibu rumah tangga sebagai edukator sebaya pada Mitra telah dilaksanakan, Mitra memiliki jumlah edukator sebanyak 6 orang.

c. Kegiatan PKM kelompok ibu rumah tangga ini juga didampingi oleh 7 kader kesehatan.

d. Guna menguatkan pemahaman edukator dari kelompok ibu rumah tangga ini tentang peran dan fungsinya maka dilakukan kegiatan pelatihan yang diselenggarakan dengan 3 kali pelatihan yang diawali dengan Focus Group Discussion (FGD) yang memiliki tujuan untuk mengukur persepsi awal pada kelompok ibu rumah tangga tentang perawatan bayi BBLR di rumah. Untuk menunjang kebutuhan pelatihan tim pelaksana juga menyediakan modul pelatihan.

e. Selama pelatihan pada kelompok ibu rumah tangga tim pelaksana telah melakukan pengukuran pencapaian sebagai dampak pelatihan yaitu dalam bentuk pretest dan posttest, juga redemonstrasi. Adapun pencapaian kognitif dapat disimpulkan bahwa ada peningkatan pengetahuan antara sebelum dan sesudah pelatihan, baik pada pelatihan 1,2, dan 3 maupun saat demonstrasi sebagai edukator sebaya. Guna mengoptimalkan 
keberhasilan program implementasi tim pelaksana juga telah melakukan pendampingan pada kelompok ibu rumah tangga. Sebaiknya program ini dilakukan terus secara berkelanjutan.

\section{Ucapan Terima Kasih}

Direktorat Riset dan Pengabdian Kepada Masyarakat. Kementerian Riset, Teknologi, dan Pendidikan Tinggi Indonesia yang telah mendanai kegiatan ini.

\section{Daftar Pustaka}

[1] Dinas Kesehatan Kabupaten Jember. (2014). Laporan Tahunan Dinas Kesehatan Kabupaten Jember.

[2] Dinas Kesehatan Kabupaten Jember. (2017). Profil Kesehatan Kabupaten Jember 2016. http://www.depkes.go.id

[3] Ikatan Dokter Anak Indonesia (IDAI). (2014). Indonesian Pediatric Society. Bayi BBLR. http://idai.or.id.

[4] Indriyani, D. Asih, S.W., dan Wahyuni, S. (2018). Perawatan Bayi Melalui Pendekatan Maternal Sensitivity Model (MSM) Berbasis Keluarga. Yogyakarta: Pustaka Panasea

[5] Gomella, T.L., Cunningham, M.D., Eyal, F.G., et al. (2013). Neonatology: Management, Procedures, OnCall, Problems, Diseases, and Drugs. $7^{\text {th }}$ Edition. Lange; 62:427-437

[6] Kusumawardani, P.A dan Cholifah. (2019) Hubungan Sikap Ibu dengan Pelaksanaan Metode Kanguru (Kangoroo Mother Care) pada Bayi Berat Badan Lahir Rendah di RS Siti Khodijah Sepanjang. ojs.umsida.ac.id

[7] Lestari, T.B., Arif, Y.S dan Alit, N.K., (2019). Faktor Pelaksanaan Kangaroo Mother Care Pada Bayi BBLR. https://e-journal.unair.ac.id

[8] Pantiawati I. (2010). Bayi dengan BBLR (Berat Badan Lahir Rendah). Yogyakarta: Nuha Medika

[9] Saputra, L. (2014). Pengantar Asuhan Neonatus, Bayi, dan Balita. Penerbit Binarupa Aksara : Tangerang Selatan.

[10] The Maternal and Child Health Integrated Program (MCHIP). (2012). Kangaroo Mother Care. 